\title{
Potentials of Bio Fermented Rice Husk Meal as a Replacement to Brewer's Dried Grain in Finisher Broiler's Diet
}

\author{
J. N. Ikpe ${ }^{1}$, E. C. Oko ${ }^{1} \&$ I. C. Vining-Ogu ${ }^{2}$ \\ 1 Department of Agricultural Technology, Akanu Ibiam Federal Polytechnic, Unwana Afikpo, Ebonyi State, \\ Nigeria \\ 2 Department of Science Laboratory Technology, Akanu Ibiam Federal Polytechnic, Unwana Afikpo, Ebonyi \\ State, Nigeria \\ Correspondence: J. N. Ikpe, Department of Agricultural Technology, School of Industrial Technology, Akanu \\ Ibiam Federal Polytechnic, PMB 1007, Unwana Afikpo, Ebonyi State, Nigeria. E-mail: juliananikpe@gmail.com
}

Received: October 20, 2018

Accepted: November 23, 2018

Online Published: January 15, 2019

doi:10.5539/jas.v11n2p533

URL: https://doi.org/10.5539/jas.v11n2p533

\begin{abstract}
Generation of rice husk waste is currently increasing in Nigeria leading to piles of heaps of the rice husk around the rice mills. Production cost for broilers has risen tremendously due to high cost of feed ingredients one of which is Brewer's Dried Grain (BDG). Rice husk has been identified as a feed stuff but it contains high fibre and is abrasive which hindered its utilization as feed ingredient in broiler production. This research was then, conducted to determine the effect of replacing BDG with bio fermented rice husk in finisher broiler's diet. Four treatment diets were formulated. T1 (control) contained 15\% BDG while in T2, T3 and T4 bio fermented rice husk meal replaced BDG at $33.33 \%, 66.67 \%$ and $100 \%$ respectively. The diets were assigned to 120 broilers of 28 days old in a complete randomized design of 10 broilers each replicated 3 times. The performance of the broilers was observed for 28 days. The broilers were slaughtered to obtain the carcass and organ characteristics. The daily weight gain was similar $(\mathrm{P}>0.05)$ among the groups while feed intake was highest for T4 group and no mortality was recorded. The percentage live weight of all the carcass and organ characteristics were similar $(\mathrm{P}>0.05)$ among the treatment groups except the breast muscle which reduced for broilers on the test ingredient. The cost of producing the treatment diets was highest for control diet while cost of feeding broilers to a kilogram weight was least for the control group. The research concluded that though the fermented rice husk had a potential to substitute BDG in the diet of finisher broilers, there was an indication of high production cost.
\end{abstract}

Keywords: bio-fermented, brewer's dried grain, finisher broilers, performance, rice husk

\section{Introduction}

Rice husk is an agro waste product generated during the milling of rice grain. Rice husk is currently produced in large quantity in Nigeria due to the increasing level of rice production in the country. The annual rice production in Nigeria has increased from 5.5 million tonnes in 2015 to 5.8 million tonnes in 2017 (RIFAN, 2017) and for every $1000 \mathrm{kgs}$ of paddy milled, about $220 \mathrm{kgs}(23 \%)$ of husk is produced (Koteswara, Pranav, \& Anusha, 2012; Moraes et al., 2014; Benassi et al., 2015). Presently, heaps of rice husks has continued to rise in most milling locations as it is mostly either burnt for heat or dumped as a waste in the majority of rice producing countries (Nwofoke, 2016). Disposing and evacuating the rice dumps is urgently necessary because of the impending environmental hazards, degradation and pollution it poses to the people and the environs (Koteswara, Pranav, \& Anusha, 2012; Haryana, 2018). The exploitation of agro by-products and farm wastes as alternative feed ingredient for poultry and livestock feeding trials has been the current trend in animal production and the potentials of these agro-wastes are yet to be well discovered. Rice husk has long been identified as a feedstuff (Oyenuga, 1968, Jacquie, 2015) but its problem of high silica, high fibre and abrasive nature make its degradation difficult thereby limiting its utilization as feed ingredient for animals. Different degradation techniques abound which has the tendency of degrading materials thereby reducing its abrasiveness. Methods such as soaking in hot water, irradiation, acid and alkaline hydrolyses, ensiling, fermentation and use of enzymes and antibiotics have been suggested to have the tendency of reducing the limiting factors in rice husk utilization (Dierick et al., 1989; Longe, 1998; Cobianchi et al., 2012; Jiaying et al., 2016). Fermentation process which can either be solid substrate fermentation or submerged fermentation can produce several value-added products to agricultural waste and by- 
products. The current high cost of feeding animals especially the mono gastric animals, due to high cost of conventional feed ingredients, as a result of pressure on them, by human and industries has necessitated the need to intensify effort on the discovery of alternative feed ingredients in feeding the animals. Such earlier research efforts resulted to the discovery of Brewer's Dried Grain (BDG) in feeding animals. Previously, the BDG was a heap of waste from brewery industries and these industries have to spend huge money for it to be evacuated, but today, it has become one of the major feed ingredient that is used as an extender in poultry feed formulation. Unfortunately these feed ingredients are now expensive and scarce due to pressure on it, a situation which has contributed to high cost of producing poultry and the resultant unaffordable of the products.

This study was therefore designed to determine the effect of using bio-fermented rice husk, as a replacement to Brewer's Dried Grain in finisher broiler diet.

\section{Materials and Methods}

\subsection{Study Area}

The research was conducted at the Teaching and Research Farm, Department of Agricultural Technology, Akanu Ibiam Federal Polytechnic Unwana, Ebonyi State. Unwana is in tropical rain forest zone of Nigeria.

\subsection{Collection of the Rice Husk}

The rice husk used for the research was obtained from one of the numerous rice mills at Eke market in Afikpo, Ebonyi State, Nigeria. The rice husk was transported to the Teaching and Research Farm of Akanu Ibiam Federal Polytechnic, Unwana, Ebonyi State, Nigeria.

\subsection{Nature and Sieve Analysis of the Rice Husk Used for the Research}

The rice husk used for the research comprises of variable sizes of particles of rice husk.

The sieve analysis of $100 \mathrm{gm}$ of the rice husk done using a British standard meshes of $500 \mu, 425 \mu, 250 \mu, 180$

$\mu$, pan and a sensitive digital scale is as follows:

$500 \mu=69.2 \% ; 425 \mu=9.02 \% ; 250 \mu=8.11 \% ; 180 \mu=6.48 \%$; Less than $180 \mu=7.17 \%$.

\subsection{Degradation of the Rice Husk}

Biofermentation of rice husk was carried out according to the procedure described by Fasuyi and Olumuyiwa (2012). A mixture of rice husk, water and Blackstrap molasses syrup was made in the ratio of $60 \mathrm{Kg}$ to 60 liters to 3 liters respectively and was compressed into 150 liters capacity plastic container. The mixture was compressed manually as it was poured in, till the container was about $3 / 4$ filled. To ensure anerobic condition, the container was carefully covered with thick nylon covering. Sand was poured on top to the rest of the space and another nylon spread across to cross the rilm of the container before covering with its lid. The fermentation took place for twenty one days after which the container was opened. The layer of sand was gently removed and the husk was poured out into a clean slab and sun dried till to about $12 \%$ moisture content. Proximate composition of the biofermented rice husk and untreated rice husk was analyzed as described by AOAC (2000). The dried bio fermented rice husk was used for the formulation of the treatment diets.

\subsection{Experimental Birds and Design}

A total of 120 Marshal breed of broilers of 28 days of age were used for the experiment. The broilers were randomly assigned to four treatment goups in a Completely Randomized Design (CRD). Each treatment group was replicated 3 times to obtain a total of 12 groups of 10 broiler each. Treatment 1 was the control group. Treatments 2,3 and 4 contained bio fermented rice husk at 5\%,10\% and $15 \%$ inclusion rates respectively. The broilers were randomly assigned to an experimental units partitioned $1 \mathrm{~m}$ by $1 \mathrm{~m}$ each and raised under a deep liter system of management. Feed and water were given ad-libitum and proper routine management practices and medications were adopted strictly in accordance with approved established standard. The feeding trial lasted for 28 days.

\subsection{Data Collection}

\subsubsection{Performance}

The broilers were weighed at the beginning and end of the experiment to obtain their weight gain. Feed intake was determined by subtracting the weight of the leftover feed from the weight of feed offered after 24 hours. Feed conversion ratio was obtained by dividing the daily feed intake with daily weight gain while mortality was monitored during the course of the research. 


\subsubsection{Carcass and Organ Characteristics}

At the end of the 28 days feeding trial, 3 broilers were randomly selected from each replicate for carcass and organ weight assessment. The broilers were starved of feed for 12 hours prior to slaughter while water was provided. The broilers were weighed to obtain the live weight and then slaughtered. Slaughtering was done in accordance with approved national established standard by severing the jugular vein with a sharp knife. The carcasses were dressed to obtain the dressed weight, eviscerated and cut into parts according to the method of (Okorie, 2006) and weighed. The weights obtained were expressed as a percentage of live weight.

\subsubsection{Cost Implication/Profitability}

The cost of feed was ascertained based on the prevailing prices of the component feed ingredients. The cost of the test ingredient was calculated based on the cost of procuring the molasses used for the research. Other costs including medication and labor which were constant for all treatments were not included in the analysis.

\subsection{Experimental Diets}

A total of 4 experimental diets were formulated for the research. $\mathrm{T}_{1}$ which was the control contained no rice husk. $\mathrm{T}_{2}, \mathrm{~T}_{3}$ and $\mathrm{T}_{4}$ contained bio-fermented rice husk. The rice husk replaced Brewer's Dried Grain at 33.33\%, $66.67 \%$ and $100 \%$ for $\mathrm{T}_{2}, \mathrm{~T}_{3}$ and $\mathrm{T}_{4}$ in each of these diets on weight to weight basis. The nutrient composition of the diets was analyzed as described by AOAC (2000) while the metabolizable energy of the biofermented rice husk was calculated using the prediction equation as reported by Pauzenga (1985). The ingredient composition of the experimental diets is presented in Table 1.

Table 1. Ingredient composition of the experimental diets

\begin{tabular}{|c|c|c|c|c|}
\hline \multirow{2}{*}{ Ingredients } & \multicolumn{4}{|c|}{ Dietary levels (\%) } \\
\hline & $\mathrm{T}_{1}(0.00)$ & $\mathrm{T}_{2}(5.00)$ & $\mathrm{T}_{3}(10.00)$ & $\mathrm{T}_{4}(15.00)$ \\
\hline Maize $(9 \% \mathrm{CP})$ & 55.00 & 55.00 & 55.00 & 55.00 \\
\hline Soya Bean Meal (44\%CP) & 5.00 & 5.00 & 5.00 & 5.00 \\
\hline Groundnut Cake (45\%CP) & 13.00 & 13.00 & 13.00 & 13.00 \\
\hline Bio fermented rice husk Meal $(4.22 \% \mathrm{CP})$ & 0.00 & 5.00 & 10.00 & 15.00 \\
\hline Brewer's Dried Grain $(27 \% \mathrm{CP})$ & 15.00 & 10.00 & 5.00 & 0.00 \\
\hline Fish Meal $(63 \% \mathrm{CP})$ & 3.00 & 3.00 & 3.00 & 3.00 \\
\hline Blood Meal (77\%CP) & 3.00 & 3.00 & 3.00 & 3.00 \\
\hline Bone Meal (nil) & 5.00 & 5.00 & 5.00 & 5.00 \\
\hline$* *$ Premix & 0.25 & 0.25 & 0.25 & 0.25 \\
\hline Lysine & 0.25 & 0.25 & 0.25 & 0.25 \\
\hline Methionine & 0.25 & 0.25 & 0.25 & 0.25 \\
\hline Common salt & 0.25 & 0.25 & 0.25 & 0.25 \\
\hline Total & 100 & 100 & 100 & 100 \\
\hline \multicolumn{5}{|c|}{ Analysed nutrient composition of the experimental diets } \\
\hline Crude protein, $\%$ & 21.23 & 20.12 & 19.62 & 19.24 \\
\hline Crude fiber, $\%$ & 7.35 & 9.74 & 9.85 & 12.98 \\
\hline Crude fat, $\%$ & 3.96 & 3.92 & 4.19 & 4.06 \\
\hline *Metabolizable energy $(\mathrm{kcal} / \mathrm{kg})$ & 2945.33 & 2918.66 & 2842.41 & 2812.46 \\
\hline
\end{tabular}

Note. ${ }^{* *}$ To provide the following per kilogram of feed; vit A 10,000IU; vit. D3 1,500 IU; vit. E 2 mg; riboflavin $3 \mathrm{mg}$; pantothenic acid $10 \mathrm{mg}$; nicotinic acid, $2.5 \mathrm{mg}$; choline $3.5 \mathrm{mg}$; folic acid $1 \mathrm{mg}$; magnesium $56 \mathrm{mg}$; lysine $1 \mathrm{mg}$; iron $20 \mathrm{mg}$; zinc $50 \mathrm{mg}$; cobalt $1.25 \mathrm{mg}$. $* \mathrm{ME}=35 \times \% \mathrm{CP}+81.8 \times \% \mathrm{EE}+35.5 \times \% \mathrm{NFE}$, where, ME $=$ Metabolizable energy, $\mathrm{CP}=$ Crude protein, $\mathrm{EE}=$ Ether extract, NFE $=$ Nitrogen free extract.

\subsection{Data Analysis}

The data obtained from this study, were subjected to statistical analysis using analysis of variance procedure and computed with IBM SPSS version 22. Significantly difference $(\mathrm{P}<0.05)$ means were compared using Duncan Multiple Range Test (Duncan, 1955). 


\section{Results and Discussion}

\subsection{Proximate Composition}

The result of the proximate analysis of the bio fermented rice husk meal used for the study is presented in Table 2. The result showed that the treated rice husk meal contains $4.22 \%$ crude protein, $37.34 \%$ crude fiber, 2.90 ether extract., $17.68 \%$ ash and calculated nitrogen free extract of $27.86 \%$. The result when compared with the result obtained from non-treated rice husk showed that bio fermentation decreased the crude protein, crude fibre and ether extract content of the rice husk while the ash content increased. The crude protein level of the biofermented rice husk in the present research did not improve contrary to the expectation that addition of molasses which contain up to $44 \mathrm{~g} \mathrm{CP} / \mathrm{kg} \mathrm{DM}$ (Xande et al., 2010) will rather improve the crude protein of the rice husk. A similar result was reported in the work of Kanengoni et al. (2016). However, biofermentation treatment was able to reduce crude fiber from $59.20 \%$ which was the value of crude fiber in untreated rice husk to $37.34 \%$ crude fiber for biofermented rice husk. The biofermentation process could have aided in the breakdown of the crude fibre resulting the reduction of crude fiber of the rice husk in the present research.

Table 2. Proximate composition of the bio - fermented and untreated rice husk meal

\begin{tabular}{lll}
\hline \multirow{2}{*}{ Nutrient } & \multicolumn{2}{c}{ Proximate Composition (\%DM) } \\
\cline { 2 - 3 } & Bio fermented rice husk & Untreated rice husk \\
\hline Dry matter content $(\%)$ & 90.00 & 89.03 \\
Crude Protein $(\% \mathrm{DM})$ & 4.22 & 5.24 \\
Crude fiber $(\% \mathrm{DM})$ & 37.34 & 59.20 \\
Ether extract $(\% \mathrm{DM})$ & 2.90 & 3.40 \\
Ash content $(\% \mathrm{DM})$ & 17.68 & 16.35 \\
Nitrogen Free Extract $(\% \mathrm{DM})$ & 27.86 & 4.84
\end{tabular}

Note. $\mathrm{DM}=$ Dry matter.

\subsection{Performance}

The result of the performance of the finisher broilers fed different levels of bio fermented rice husk is presented in Table 3. The result showed that the broilers in the control group $\left(T_{1}\right)$ had a significant $(P<0.05)$ highest weight which was $2468.80 \mathrm{~g}$ which was similar $(\mathrm{P}>0.05)$ with $\mathrm{T}_{3}$ and $\mathrm{T}_{4}$ which were $2416.70 \mathrm{~g}$ and $2441.70 \mathrm{~g}$ respectively while the final weight of $T_{2}$ which was $2335.40 \mathrm{~g}$ was significantly $(\mathrm{P}<0.05)$ lower than the value obtained from the control but similar $(\mathrm{p}>0.05)$ with the values obtained from $\mathrm{T}_{3}$ and $\mathrm{T}_{4}$. The Av. body weight gain and the daily weigth gain did not differ among the treatment groups while the broilers in $\mathrm{T}_{4}$ group consumed significantly highest $(\mathrm{P}<0.05)$ daily feed which was $144.21 \mathrm{~g}$ which was similar with $\mathrm{T}_{2}(136.01)$ while the broilers on the control group and $\mathrm{T}_{3}$ group consumed least feed. The Feed Conversion Ratio was least for broilers in the cotrol group which was similar with the value obtained in the $T_{3}$ group while the value obtained from the $T_{2}$ and $T_{4}$ were higher and similar with the value obtained from $T_{3}$. No mortality was recorded in the course of the experiment. Though in the present research, there was a significant difference in the final body weight of the broilers in the control group and those in $T_{2}$ group but the body weight gain and the daily weight gain of the broilers were similar among all the treatment groups and no mortality was encountered. Body weight gain and mortality are sensitive indicators of changes in the nutritional qualities of a diet (International Life Science Institute, 2003). The similarity of the finisher broilers obtained in this research on body weight gain and no mortality are indication that the treated rice husk was compatible with the BDG. Rice husk has been reported not to be ideal for inclusion in monogastric animal nutrition due to its problem of low nutrients digestibility, high silica/ash content and abrasive characteristics (Aderolu, Iyayi, \& Onilude, 2007). The similarity in weight gain of these broiler as obtained in the present research is an indication of improvement in the nutrient digestibility and absorption of the rice husk which could be due to the bio fermentation of the rice husk. The bio fermentation could have resulted in the breakdown of the nutrients in the rice husk thereby rendering the nutrients to be at par with that contained in BDG evidence of which was also seen in the proximate analysis result in which the crude fiber was reasonably broken down. The molasses used for the fermentation of the rice husk has been reported to have nutritive and appetizing quality (Pérez, 1995; Hussein et al., 2016) which could have enhanced the feed consumption of the diets containing the bio fermented rice husk which also could have led to uniformity in the body weight gain among the broilers on the test ingredient and those on the control diet. Furthermore, molasses supplement in feed has been reported to increase the production of short chain fatty 
acid such as acetic and propionic acids in the caecum of chickens (Gultemirian et al., 2014) which could have contributed to the improvement in weight gain of the broilers on the test ingredient. The result agrees with the work of (Fasuyi \& Olumuyiwa, 2012) who reported best performance indices for broilers fed rice husk fermented for 21days. The feed intake was however, highest for broilers in $\mathrm{T}_{4}$ group and then the $\mathrm{T}_{2}$ group which was an indication that the broilers in these treatment groups consumed more feed to gain the similar weight and which also accounted for the higher and similarity in the feed conversion ratio for the broilers in the two treatment groups.

Table 3. Performance of finisher broilers fed different levels of bio fermented rice husk meal

\begin{tabular}{llllll}
\hline \multirow{2}{*}{ Parameters } & \multicolumn{5}{c}{ Treatment levels (\%) } \\
\cline { 2 - 6 } & $\mathrm{T}_{1}(0.00)$ & $\mathrm{T}_{2}(5.00)$ & $\mathrm{T}_{3}(10.00)$ & $\mathrm{T}_{4}(15.00)$ & SEM \\
\hline Av. Initial Body Weight (g) & 759.52 & 725.56 & 738.10 & 728.57 & 27.55 \\
Av. Final Body Weight (g) & $2468.80^{\mathrm{a}}$ & $2335.40^{\mathrm{b}}$ & $2416.70^{\mathrm{ab}}$ & $2441.70^{\mathrm{ab}}$ & 51.07 \\
Av. Body Weight Gain (g) & 1709.23 & 1623.51 & 1678.57 & 1713.09 & 50.31 \\
Av. Daily Weight Gain(g) & 63.30 & 60.13 & 62.18 & 63.45 & 1.86 \\
Av. Daily Feed Intake(g) & $128.34^{\mathrm{b}}$ & $136.01^{\mathrm{ab}}$ & $134.93^{\mathrm{b}}$ & $144.21^{\mathrm{a}}$ & 3.70 \\
FCR(Daily feed intake/DWG) & $2.03^{\mathrm{b}}$ & $2.27^{\mathrm{a}}$ & $2.18^{\mathrm{ab}}$ & $2.28^{\mathrm{a}}$ & 0.09 \\
Mortality & - & - & - & - & \\
\hline
\end{tabular}

Note. Without superscript $=$ not significant. Means with different superscript in the same row differ significantly $(\mathrm{P}$ $<0.05) . \mathrm{SEM}=$ Standard Error Mean. Av = average. FCR $=$ feed conversion ratio. $\mathrm{DWG}=$ Daily weight gain.

\subsection{Carcass and Organ Characteristics}

The result of carcass and organ analysis is presented in Table 4. The result showed that the carcass and organ characteristics calculated in the percentage live weight of the broilers had no significant difference $(\mathrm{P}>0.05)$ among the treatment groups in all the parameters analyzed except in the breast muscle. The breast muscle of the broilers on the control group had a significant higher value which was $18.28 \%$ while the values for $T_{2}, T_{3}$ and $T_{4}$ were similar. The breast muscle is the most valuable portion of the chicken carcass with high significant economic impact in the market (Scheuermann et al., 2003; Zuidhof et al., 2014). The significant reduction in breast muscle obtained in the present research is an indication of inadequacy of bio fermented rice husk to replace BDG since this most valuable carcass of significant economic importance was negatively affected. However in the present research, the liver, which is the most voluminous gland present in animal body that plays a fundamental role in the digestion of nutrients, through the production of bile, liver enzymes, in the metabolism of sugar, proteins, and fats (Suzuki et al., 2008), did not differ significantly (P > 0.05). Increased liver size in poultry has been associated with the presence of anti-nutritional factors (Ledoux et al., 1992; Bailey et al., 2000; Oloruntola, 2018). The similarity in the result obtained in liver size of the broilers in the present research is an indication that bio fermented rice husk may be devoid of anti-nutritional factor. 
Table 4. Carcass and organ characteristics of finisher broilers fed different levels of bio fermented rice husk meal

\begin{tabular}{llllll}
\hline \multirow{2}{*}{ Parameters } & \multicolumn{5}{c}{ Dietary levels \% } \\
\cline { 2 - 5 } & $\mathrm{T}_{1}(0.00)$ & $\mathrm{T}_{2}(5.00)$ & $\mathrm{T}_{3}(10.00)$ & $\mathrm{T}_{4}(15.00)$ & SEM \\
\hline Live weight (LW) (g) & 2366.67 & 2466.67 & 2416.67 & 2233.33 & 163.92 \\
Dressed weight (\%LW) & 93.11 & 91.55 & 91.53 & 92.60 & 2.07 \\
Eviscerated weight (\%LW) & 76.60 & 73.21 & 75.27 & 76.91 & 4.04 \\
Breast muscle (\%LW) & $18.28^{\mathrm{a}}$ & $16.22^{\mathrm{b}}$ & $16.22^{\mathrm{b}}$ & $15.92^{\mathrm{b}}$ & 0.79 \\
Thigh/drumstick (\%LW) & 19.57 & 19.93 & 19.10 & 19.13 & 2.47 \\
Wing (\%LW) & 6.78 & 6.67 & 7.62 & 8.00 & 0.91 \\
Back (\%LW) & 10.95 & 10.65 & 12.00 & 11.90 & 0.58 \\
Neck (\%LW) & 5.23 & 5.39 & 4.64 & 5.41 & 0.56 \\
Head(\%LW) & 1.92 & 2.30 & 2.11 & 1.81 & 0.40 \\
Heart (\%LW) & 0.58 & 0.58 & 0.41 & 0.45 & 0.09 \\
Liver/gallbladder (\%LW) & 3.08 & 3.06 & 2.74 & 2.29 & 0.32 \\
Gizzard (\%LW) & 3.65 & 3.50 & 3.15 & 3.45 & 0.27 \\
Vent (\%LW) & 3.39 & 3.39 & 3.39 & 3.15 & 0.19 \\
Intestinal length (cm) & 255.33 & 233.67 & 240.33 & 255.00 & 11.40 \\
\hline
\end{tabular}

Note. Without superscript $=$ not significant. Means with different superscript in the same row differ significantly $(\mathrm{P}$ $<0.05)$. SEM $=$ Standard Error Mean. $\mathrm{LW}=$ Live weight.

\subsection{Cost Implication/Profitability}

The result of the profitability of feeding broilers with diet containing bio fermented rice husk is presented in table 5. The result showed that cost of producing a kilogram weight of the control diet was N142.25 while the cost for $T_{2}, T_{3}$ and $T_{4}$ diets were $\$ 139.50, \$ 136.75$ and $\$ 134.00$ respectively indicating a reduction in cost as inclusion rate of the test ingredient increased. The cost of feeding broilers to a kilogram live weight was however lower for the control group due to the reduction in feed intake while the cost of feeding the broilers to a kilogram live weight was higher for $T_{2}, T_{3}$ and $T_{4}$ due to the increase in feed intake observed in the present research.

Table 5. Profitability of feeding finisher broilers with bio fermented rice husk meal

\begin{tabular}{|c|c|c|c|c|c|}
\hline \multirow{2}{*}{ Parameters } & \multicolumn{5}{|c|}{ Dietary levels $(\%)$} \\
\hline & $\mathrm{T}_{1}(0.00)$ & $\mathrm{T}_{2}(5.00)$ & $\mathrm{T}_{3}(10.00)$ & $\mathrm{T}_{4}(15.00)$ & SEM \\
\hline Av. Final live weight (g) & $2468.80^{\mathrm{a}}$ & $2335.40^{\mathrm{b}}$ & $2416.70^{\mathrm{ab}}$ & $2441.70^{\mathrm{ab}}$ & 51.07 \\
\hline AV. Weight Gain Within the Period (28 days) (g) & 1709.23 & 1623.51 & 1678.57 & 1713.09 & 50.32 \\
\hline Av. Feed Consumed per Broiler Within 28 days (g) & $3593.52^{\mathrm{d}}$ & $3808.28^{\mathrm{b}}$ & $3778.04^{\mathrm{c}}$ & $4037.88^{\mathrm{a}}$ & 1.04 \\
\hline Feed price per kg $(\mathbb{N})$ & 142.25 & 139.50 & 136.75 & 134.00 & - \\
\hline Cost of feed consumed per broiler within 28 days $(\mathrm{N})$ & 511.18 & 531.26 & 516.65 & 540.10 & - \\
\hline Feed cost per broiler per $\mathrm{Kg}$ weight gain within 28 days $(\mathbb{N})$ & $299.60^{\mathrm{d}}$ & $327.23^{\mathrm{a}}$ & $307.73^{\mathrm{c}}$ & $315.85^{\mathrm{b}}$ & 0.02 \\
\hline Feed cost per broiler per kg live weight $(\mathrm{N})$ & $207.06^{\mathrm{d}}$ & $227.47^{\mathrm{a}}$ & $213.78^{\mathrm{c}}$ & $221.60^{\mathrm{b}}$ & 0.20 \\
\hline
\end{tabular}

Note. Without superscript $=$ not significant. Means with different superscript in the same row differ significantly (P $<0.05) . \mathrm{SEM}=$ Standard Error Mean. Av = average.

\section{Conclusion}

It can be concluded from the findings of this research that the bio fermented rice husk meal has potentials to replace BDG in the diet of finisher broilers as the weight gain of the broilers were similar. Also, the bio fermented rice husk is not toxic as there was no mortality and no increase in liver size of the broilers in the present research. However, replacing BDG with bio fermented rice husk increased the feeding cost of the finisher broilers.

\section{Acknowledgements}

The researchers immensely wish to thank the management of Akanu Ibiam Federal Polytechnic Unwana for giving us the opportunity to participate in the Institution Based Research. We also thank the Tertiary Education 
Trust Fund (TETfund) of the Federal Government of Nigeria for providing us with a research grant to explore the Potentials of Rice Husk (a hitherto increasingly-generated agricultural waste) as a replacement to Brewer's Dried Grain in finisher broiler's diet.

\section{References}

A.O.A.C. (Association of Official Analytical Chemists). (2000). Official methods of analysis (17th ed.). A.O.A.C International Virginia, USA.

Aderolu, A. Z., Iyayi, E. A., \& Onilude, A. A. (2007). Changes in Nutritional Value of Rice Husk during Trichoderma viride Degradation. Bulgarian Journal of Agricultural Science, 13, 583-589.

Bailey, C. A., Stipanovic, R. D., Ziehr, M. S., Haq, A. U., Sattar, M., Kubena, L. F., ... Vieira, R. (2000). Cottonseed with a high (+) to (-)-gossypol enantiomer ratio favorable to broiler production. J. Agric. Food Chem., 48, 5692-5695. https://doi.org/10.1021/jf000211n

Benassi, L., Franchi, F., Catina, D., Cioffi, F., Rodella, N., Borgese, L., ... Bontempi, E. (2015). Rice Husk Ash to Stabilize Heavy Metals Contained in Municipal Solid Waste Incineration Fly Ash: First Results by Applying New Pre-treatment Technology. Materials (Basel, Switzerland), 8(10), 6868-6879. https://doi.org/ $10.3390 / \mathrm{ma} 8105346$

Cobianchi, J. V., Oliveira, A. S., Campos, J. M. D., Guimaraes, A. V., Valadares, S. D., \& Cobianchi, F. P. (2012). Productive performance and efficiency of utilization of the diet components in dairy cows fed castor meal treated with calcium oxide. Rev Bras Zootecn, 41, 2238-48. https://doi.org/10.1590/S1516-35982012001 000015

Dierick, N. A., Varaeke, I. J., Demayer, D. I., \& Decuypere, J. A. (1989). Approach tothe energetic importance of fibre digestionin pigs 1. Importance of fermentation in theoverall energy supply. Anim. Feed Sci. Technol., 23, 141-167. https://doi.org/10.1016/0377-8401(89)90095-3

Duncan, D. B. (1955). Multiple range and multiple F tests. Biometrics, 11, 1-42. https://doi.org/10.2307/3001478

Fasuyi, A. O., \& Olumuyiwa, T. A. (2012). Evaluating Nutritional Potential of Bio fermented Rice husk in Broilers Diets. American Journal of Food Technology, 7, 726-735. https://doi.org/10.3923/ajft.2012. 726.735

Gultemirian, M. L., Corti, H. R., Chaia, A. P., \& Apella, M. C. (2014). Fermentation in vitro of a mixture of dietary fibers and cane molasses by the cecal microbiota: Application on mineral absorption through the laying hen's colonic epithelium. Anim Sci Technol, 191, 79-82. https://doi.org/10.1016/j.anifeedsci.2014. 01.019

Haryana. (2018). Mills dump rice husk ash in open, release waste water in empty plots-The Tribune News Service. Retrieved Feb 5, 2018, from https://www.tribuneindia.com/news/haryana/mills-dump-ricehusk-ash-in-open-release-waste-water-in-empty-plots/538668.html

Hussein, A. S., Al Ghurair, J., John, P. G. K., Habib, H. M., \& Sulaiman, M. (2016). Graded levels of sugar syrup in broiler rations and its effect on growth performance and blood biochemical parameters. Animal Nutrition, 2(3), 180-185. https://doi.org/10.1016/j.aninu.2016.07.002

International Life Science Institute (ILSI). (2003). Best practices for the conduct of animal studies to evaluate crops genetically modified for input traits. Int. Life Sci. Inst., Washington, DC.

Jacquie, J. (2015). Common Feed Ingredients in Poultry Diets. Retrieved from http://articles.extension.org/ pages/68432/common-feed-ingredients-in-poultry-diets

Jiaying, L., John, P. B., Klaus, H. Zhixuan, W., \& Gordon, M. (2016). A comparison of chemical treatment methods for the preparation of rice husk cellulosic fibers. International Journal of Environmental \& Agriculture Research, 5(1), 2545-1850.

Kanengoni, A. T., Nkosi, B. D., Chimonyo, M., Ndimba, B., \& Dzama, K. (2016). Effects of whey, molasses and exogenous enzymes on the ensiling characteristics, nutrient composition and aerobic stability of maize cobs. S. Afr. J. Anim. Sci., 46. https://doi.org/10.4314/sajas.v46i2.1

Koteswara, R. D., Pranav, P. R. T., \& Anusha, M. (2012). Stabilization of expansive soil with rice husk ash, lime gypsum-An experimental study. International Journal of Engineering Science and Technology, 18(6), 131-139. 
Ledoux, D. R., Brown, T. P., Weibking, T. S., \& Rottinghaus, G. E. (1992). Fumonisin toxicity in broiler chicks. J. Vet. Diagn. Invest, 4, 330-333. https://doi.org/10.1177/104063879200400317

Longe, O. G. (1998). Meeting the energy needs of non-ruminants from non-conventional feed sources in Nigeria. Paper presented at Agricultural \& Rural Management Training Institute (ARMTI), Ilorin, Nigeria.

Moraes, C. A. M., Fernandes, I. J., Calheiro, D., Kieling, A. G., Brehm, F. A., Rigon, M. R., ... Osorio, E. (2014). Review of the rice production cycle: By-products and the main applications focusing on rice husk combustion and ash recycling. Waste Management \& Research, 32(11), 1034-1048. https://doi.org/10.1177/ $0734242 X 14557379$

Nwofoke, C. (2016). Rice Husk Generation and Utilization among Households in Ebonyi State, Nigeria (M.Sc Thesis University of Nigeria Nsukka).

Okorie, K. C. (2006). Evaluation of Jacaranda mimosifolia T. (stans) leaf meal as Ingredient in finisher broilers diet. Performance carcass and organ weight Characteristics. Anim. Prod. Res. Adv., 2(1), 44-46. https://doi.org/10.4 314/apra.v2i1.36311

Oloruntola, O. D. (2018). Gliricidia Leaf Meal in Broiler Chickens Diet: Effects on Performance, Carcass, and Haemato-biochemical Parameters. Journal of Applied Life Sciences International, 18(3), 1-9.

Oyenuga, V. A. (1968). Nigeria feed and feedstuffs (3rd ed.). Ibadan University Press.

Pauzenga, U. (1985). Feeding parent stock (pp. 22-25). Zootecnia International.

Pérez, R. (1995). Molasses. Tropical Feeds and Feeding Systems, First FAO Electronic Conference.

RIFAN. (2017). Rice production in Nigeria increases to $5.8 m$ tonnes in 2017.

Scheuermann, G. N., Bilgili, S. F., Hess, J. B., \& Mulvaney, D. R. (2003). Breast muscle development in commercial broiler chickens, Poultry Science, 82, 1648-1658. https://doi.org/10.1093/ps/82.10.1648

Suzuki, K., Tanaka, M., Watanbe, N., Saito, S., Nonaka, H., \& Miyajima, A. (2008). P75 Neurotrophin receptor is a marker for precursors of stellate cells and fibroblasts in mouse fetal liver. Gastroenterology, 135(1), 270-281. https://doi.org/10.1053/j.gastro.2008.03.075

Xande, X., Archimede, H., Gourdine, J. L., Anais, C., \& Renaudeau, D. (2010). Effects of the level of sugarcane molasses on growth and carcass performance of Caribbean growing pigs reared under a ground sugarcane stalks feeding system. Trop. Anim. Health Prod., 42, 13-20. https://doi.org/10.1007/s11250-009-9379-7

Zuidhof, M. J., Schneider, B. L., Carney, V. L., Korver, D. R., \& Robinson, F. E. (2014). Growth, efficiency, and yield of commercial broilers from 1957, 1978, and 2005. Poult. Sci., 94, 1389-1397. https://doi.org/ $10.3382 / \mathrm{ps} / \mathrm{pev} 064$

\section{Copyrights}

Copyright for this article is retained by the author(s), with first publication rights granted to the journal.

This is an open-access article distributed under the terms and conditions of the Creative Commons Attribution license (http://creativecommons.org/licenses/by/4.0/). 